\title{
IMPLEMENTASI INSTRUMEN PENILAIAN SIKAP DI SDN GUNUNGSAREN BANTUL
}

\author{
Itsna Rifiana Ulfa \\ UIN Sunan Kalijaga Yogyakarta \\ rifianaulfa@gmail.com
}

\begin{abstract}
The background of the problem held by this research is to find out the implementation of attitude assessment applied in schools. The attitude or affective aspect is an important part of the learning process, but many schools only focus on cognitive aspects. A good attitude must be instilled in every student and there is on need to think about it because it is absorbed in his daily behvior. This study aims to determine whether attitude assessment has been applied to the maximum in learning and the apllication of attitude assessment techniques in learning. The research method is a qualitative field research with a descriptive approach. Obtained from observations, interviews and documentation. Interviews were conducted with PAI's teachers to find out whether the attitude assessment had been applied ti the maximum or not, observations were modw to find out the activities of teachers in assessing student's attitudes in learning, and documentation was used to take an attitude assessment and photo form that could strengthen the evidence of the findings from interviews and observations. The results of this study indicate that the assessment of attitude has been apllied in learning, it is proven that students always try to be better with the prefix that only wants to get value but this change is implemented continuously so that it becomes a babit in everyday life.
\end{abstract}

Keywords: Assessment Instruments, Attitude Aspects

\begin{abstract}
Abstrak: Latar belakang masalah diadakan penelitian ini yaitu untuk mengetahui implementasi penilaian sikap yang diterapkan dalam sekolah. Aspek sikap atau afektif merupakan bagian penting pada proses pembelajaran, tetapi banyak sekolah-sekolah hanya mementingkan pada aspek kognitif. Sikap yang baik haruslah tetanam pada diri setiap siswa dan tidak perlu untuk memikirkannya karena sudah tertanan pada perilaku kesehariannya. Penelitian ini bertujuan untuk mengetahui apakah penilaian sikap sudah diterapkan secara maksimal dalam pembelajaran dan teknik penerapan penilaian sikap di dalam pembelajaran. Metode Penelitian ini adalah penelitian lapangan yang bersifat kualitatif dengan pendekatan deskriptif. Data diperoleh dari observasi, wawancara dan dokumentasi. Wawancara dilakukan kepada Guru PAI untuk mengetahui apakah penilaian sikap sudah diterapkan secara maksimal atau belum, observasi dilakukan untuk mengetahui aktivitas guru dalam menilai sikap siswa dalam pembelajaran, dan dokumnetasi digunakan untuk mengambil form
\end{abstract}


penilaian sikap dan foto yang bisa memperkuat bukti hasil temuan dari wawancara dan observasi. Hasil penelitian ini menunjukkan penilaian sikap sudah diterapkan dalam pembelajaran, hal ini terbukti bahwa siswa selalu berusaha menjadi lebih baik dengan awalan yang hanya ingin mendapatkan nilai tetapi perubahan ini dilaksanakan dengan terus menerus sehingga menjadi kebiasaan dalam keseharian.

Kata Kunci: Instrumen penilaian, Aspek sikap

\section{PENDAHULUAN}

Dunia pendidikan menghadapi masalah yang berat, karena rendahnya kualitas pendidikan dan akan lebih memprihatinkan lagi jika melihat dari segi sikap dan moral yang sangat mengkhawatirkan terutama kalangan pelajar yang seharusnya menjadi penerus bangga tapi mempunyai moral yang mengkhawatirkan. Permasalahan dalam dunia pendidikan sudah mendapat respon dari pemerintah dengan cukup baik, terbukti dengan pembaharuan kurikulum yang dipakai dalam pendidikan. Yang awalnya pendidikan hanya menentukan pada aspek kognitif, degan kurikulum baru ini ditambah dengan aspek afektif dan aspek psikomorik juga sangat penting untuk kelangsungan pendidikan. ${ }^{1}$

Sistem pendidikan nasional yang tercantum dalam undang undang nomor 20 tahun 2013 menjelaskan bahwa pendidikan tidak hanya membentuk peserta didik yang cerdas tetapi juga membentuk kepribadian atau karakter, sehingga lahir generasi yang berkarakter yang selaras dengan nilai-nilai bangsa dan agama. Tujuan dari sistem pendidikan nasional itu sendiri adalah secara aktif peserta didik mengembangkan potensinya yaitu spiritual keagamaan, pengendalian diri, kepribadian, kecerdasan dan ketrampilan. Untuk tercapainya tujuan pendidikan seharusnya sistem pendidikan tidak hanya mengutamakan pada aspek pengetahuan tetapi juga pada aspek sikap, karena aspek sikap sama pentingnya dengan aspek pengetahuan dan ketrampilan.

Pendidikan merupakan hal sangat penting bagi perkembangan individu seseorang, masyarakat maupun negara. Sehingga pemerintah mengembangkan sistem pendidikan dengan cara membuat kurikulum baru yaitu kurikulum 2013, kurikulum

1 Mursal, Pendidikan Afektif Dalam Perspektif Hasan Langgulung, dalam jurnal Al-Fikra: Jurnal Ilmiah Keislaman, Vol. 12, No. 1, Januari - Juni 2013, hlm. 53-54. 
2013 ini mengembangkan aspek sikap, pengetahuan dan ketrampilan, sehingga penilaian dalam pembelajaran mencakup tiga aspek tersebut. ${ }^{2}$

Hingga saat ini kurikulum 2013 hadir untuk menyentuh aspek afektif. Penilaian afektif merupakan penilaian yang berkaitan dengan sikap, penilaian sikap dibagi menjadi dua yaitu sikap spiritual yang terkait dengan beriman dan bertakwa, dan sikap sosial yang terkait dengan pembentukan perserta didik yang berkahlak mulia, mandiri, demokratis dan bertangggung jawab. ${ }^{3}$

Penilaian sikap merupakan penilaian yang susah diidentifikasi karena tidak bisa hanya dinilai dalam satu kali pertemuan saja penilaian sikap harus dilaksanakan secara bertahap dan terus menerus. Penilaian sikap dapat dibagi menjadi beberapa bagian penilaian diantaranya, pertama, sikap terhadap mata pelajaran, apakah siswa mempunyai minat dalam belajar karena dengan adanya minat dalam belajar akan lebih mudah untuk menyrap materi pelajaran. Kedua, sikap terhadap guru, apakah siswa mengabaikan atau memperhatikan. Ketiga, sikap terhadap materi dari pokok pokok bahasan, materi merupakan kunci keberhasilan proses pembelajaran. Keempat, sikap hubungan sosial, contonya kerjasama, kekeluargaan dll. $^{4}$

Dengan adanya kurikulum 2013 yang menyebutkan bahwa ada tiga aspek yang seharusnya dinilai yaitu aspek afektif, aspek kognitif dan aspek psikomorik, sehingga peneliti terdorong untuk meneliti apakah sekolah sudah melakukan penilaian afektif atau hanya melakukan penilaian kognitif dan psikomotorik saja, dan jika sudah melakukan penilaian afektif teknik apa saja yang digunakan untuk penilaian. Kerena dengan dilaksanakan penilaian sikap ini dapat membentuk akhlak yang baik untuk peserta didik sehingga pembelajaran tidak hanya berhasil dalam pengetahuan saja tetapi juga dalam aspek akhlak. Dalam penelitian ini akan dibahas mengenai implementasi penilaian sikap pada SDN Gunungsaren Bantul, penilaian yang diterapkan sejak SD atau sejak dini akan lebih mudah untuk membentuk

${ }^{2}$ Shintia Kandita Tiara, Analisis Teknik Penilaian sikap Sosial Siswa dalam Penerapan Kurikulum 2013 Di SDN 1 Watulimo, dalam jurnal EduHumaniora: Jurnal Pendidikan Dasar, Vol.11 No.1, Januari 2019, hlm. 21-22

3 Peraturan Menteri Agama No. 165 Tahun 2014

${ }^{4}$ Hari Setiadi, Pelaksanaan Penilaian Pada Kurikulum 2013, dalam Jurnal Penelitian dan Evaluasi Pendidikan, Vol. 20, No. 2, Desember 2016, hlm. 169 
karakter akhlak yang baik untuk peserta didik, yang akan terus melekat pada diri siswa sehingga menjadi peserta didik yang unggul dalam pengetahuan dan akhlak.

\section{METODE DAN PENDEKATAN PENELITIAN}

Penelitian ini termasuk dalam penelitian lapangan (field research) dan menggunakan pendekatan kualitatif. Jenis penelitian kualitatif ini adalah studi kasus, yang mana meneliti keadaan dengan menggunakan cara yang sistematis dalam melakuakn pengamatan, pengumpulan, analisis dan pelaporan hasilnya. Sehingga menghasilkan data deskriptif, dimana data yang dikumpulkan lebih berupa kata-kata dan informan berhubungan secara langsung. ${ }^{5}$

Subjek penelitian merupakan sumber utama data penelitian yaitu yang mempunyai data mengenai penelitian. ${ }^{6}$ Dalam penelitian ini subjek penelitiannya adalah Guru PAI SDN Gunungsaren Bantul yang melaksanakan aktivitas pembelajaran, objek penelitian ini adalah tetang penilaian sikap spiritual dan sosial.

Teknik pengumpulan data penelitian ini ditempuh melalui tiga langkah yaitu observasi yaitu melakukan pengamatan langsung guna untuk mengumpulkan data, wawancana adalah pengumpulan data yang digunakan untuk memperoleh informasi secara langsung dari sumbernya dan dokumentasi yaotu mencari data mengenai halhal atau variabel yang berupa catatan, transkip, surat kabar, majalah, prasasti, notulen rapat, agenda, foto dan lain-lain ${ }^{7}$. Penelitian ini dilaksanakan pada minggu pertama dan kedua bulan mei.

Setelah data terkumpul dan diklarifikasi, selanjutnya adalah menganalisis data, analisis data yang digunalan dalam penelitian ini adalah metode deskriptif metode ini bertujuan untuk menyajikan deskriptif secara sistematis, faktual dan akurat mengenai fakta, sifat serta hubungan fenomena yang diselidiki. Aktivitas dalam analisis data ni berupa reduksi data, penyajian data dan penarikan kesimpulan.

\footnotetext{
${ }^{5}$ Risqyanto Hasan, Inovasi Strategi Pembelajaran Inkuiri dalam Pembelajaran, dalam Jurnal Palapa: Jurnal Studi Keislaman dan Ilmu Pendidikan, Vol. 7, No.1, Mei 2019, hlm. 34

${ }^{6}$ Syifuddin Azwar, Metode Penelitian, (Yogyakarta: Pustaka Pelajar, 1998), hlm.34

${ }^{7}$ Suharsimi Arikunto, Prosedur Penelitia: Suatu Pendekatan Praktik, (Jakarta: Bumi Aksara, 2007), hlm. 156
} 


\section{HASIL DAN DISKUSI}

Kurikulum 2013 sudah mulai dilaksanakan oleh SDN Gunungsaren pada tahun 2015, pelaksanaan kurikulum 2013 diuji cobakan pada kelas 1 dan 4, sampai tahun ini sudah semua kelas menggunakan kurikulum 2013. Dalam penerapan kurikulum 2013 guru juga mulai menerapkan penilaian aspek afektif, kognitif dan psikomotorik. Dalam pembahasan kali ini peneliti hanya membahas tentang penilaian afektif yang dilakukan guru PAI, apakah guru PAI sudah mulai menerapkan penilaian afektif dan teknik apa yang digunakan untuk penilaian afektif.

Hasil penelitian melalui wawancara dan observasi terhadap penerapan penilaian aspek afektif menunjukkan bahwa guru PAI sudah menerapkan penilaian afektif, penilaian afektif dilaksanakan dengan beberapa proses yaitu perencanaan, pelaksanaan dan dampak dari penilaian afektif.

\section{Perencanaan penilaian afektif}

Perencanaan penilaian afektif yang akan dilakukan tercantum dalam rencana pelaksanaan pembelajaran dicantumkan dalam instrumen dan rubik penilaian. Penilaian afektif yang dilakukan adalah observasi yang dilakukan oleh guru, penilaian diri yaitu menyebarkan formulir ke siswa, penilaian teman sejawat dan jurnal yaitu mengisi kegiatan keseharian yang disaksikan oleh orang tua. Penilaian afektif untuk ranah sosial penilaian dilakukan oleh guru PAI dan guru kelas, sedangkan untuk penilaian afektif ranah spiritual hanya dilakukan oleh guru PAI. ${ }^{8}$

Instrumen penilaian afektif

Dalam proses pembelajaran di sekolah, hasil belajar afektif yang penting untuk diukur adalah sikap dan minat terhadap suatu nilai-nilai tertentu dalam mata pelajaran umum maupun agama serta kemauan untuk melakukan dan membiasakan sikap atau nilai nilai tersebut. ${ }^{9}$

Instrumen penilaian non tes yang digunakan dalam melakukan penilaian afektif adalah teknik observasi, penilaian diri, penilaian teman, wawancara, jurnal.

\footnotetext{
8 Wawancara dengan ibu Kartika Juliana, S.Pd, tentang perencanaan penilaian sikap, pada hari Kamis tanggal 9 Mei 2019, pukul 09.30.

9 Sukiman, Sistem Penilaian Pembelajaran, (Yogyakarta: Media Akademi, 2017), hlm. 110
} 


\section{Teknik Observasi}

Teknik observasi merupakan teknik suatu proses pengamatan dan pencatatan sistematis tentang perilaku siswa dalam proses belajar peserta didik, observasi harus dilakukan pada saat proses kegiatan berlangsung. ${ }^{10}$ Pengamatan terlebih dahulu harus menetapkan aspek-aspek perilaku yang akan di observasikan, kemudian dibuat pedoman agar memudahkan dalam observasi. Pedoman pengamatan terdiri dari;

a. Pedoman pengamatan perhatian dan keaktifan siswa ketika proses pemabelajaran

\begin{tabular}{|c|l|l|l|l|l|l|l|}
\hline \multirow{2}{*}{ No. } & \multirow{2}{*}{ Nama } & \multicolumn{4}{|c|}{ Aspek penilaian } & Jumlah \\
\hline & & 1 & 2 & 3 & 4 & 5 & \\
\hline 1. & Ahmad & & & & & & \\
\hline 2. & Ana & & & & & & \\
\hline 3. & Alif & & & & & & \\
\hline & & & & & & & \\
\hline
\end{tabular}

Ket : $\quad 1=$ kehadiran mengikuti pelajaran

$2=$ perhatisan selama proses pembalajaran

$3=$ keaktifan dalam kerjasama kelompok

$4=$ kebaranian untuk bertanya

5 = keberanian untuk mengungkapkan pendapat

Penskoran untuk penilaian :

$$
\begin{array}{rlrl}
\text { Skor: } & 5=\text { sangat baik } & 4=\text { cukup } \quad 3=\text { cukup } \\
2=\text { Kurang } & 1=\text { Sangat kurang }
\end{array}
$$

b. Pedoman pengamatan penampilan diskusi kelas

Kelas/semester :

Jumlah siswa

Mata Pelajaran

${ }^{10}$ Ibid., hlm. 113 


\begin{tabular}{|c|c|c|c|c|c|c|c|}
\hline No & Indikator & 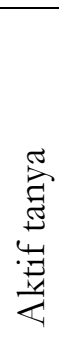 & 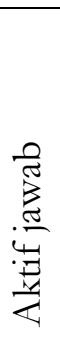 & 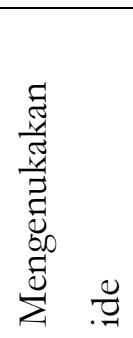 & 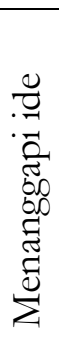 & 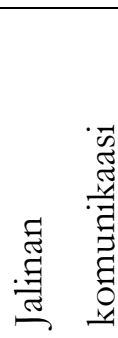 & $\begin{array}{r}\overrightarrow{0} \\
\frac{d}{\infty}\end{array}$ \\
\hline 1. & Ana & & & & & & \\
\hline 2. & Alif & & & & & & \\
\hline 3. & Ahmad & & & & & & \\
\hline 4. & & & & & & & \\
\hline 5. & & & & & & & \\
\hline 6. & & & & & & & \\
\hline
\end{tabular}

Penskoran dan penafsiran hasil :

$$
\begin{array}{rlr}
\text { Skor : } & 1=\text { Tidak pernah } & 4=\text { Sering } \\
2 & =\text { Jarang } \quad 5=\text { Selalu } \\
3 & =\text { Kadang-kadang } &
\end{array}
$$

\section{Penilaian diri}

Penilaian diri merupakan Teknik penilaian dengan cara meminta kepada siswa membuat ulasan tentang mengemukakan dirinya baik tentang prestasi atau kelebihan dan kekurangan dirinya dalam kontek pencapaian kompetensi. ${ }^{11}$

Ada beberapa Teknik yang dapat digunakan untuk pelaksanaan diri ini yaitu: laporan diri, skala sikap, skala minat, dan biografi. Tetapi yang digunakan dalam penilaian oleh Guru hanya laporan diri, skala sikap dan skala minat.

\section{a. Laporan Diri}

Laporan diri merupakan laporan tentang aktifitas peserta didik yang dilakukan dalam kehidupan sehari-hari. Lembar laporan yang dilaksanakan oleh guru PAI yaitu lembar laporan kebiasaan membaca Al-Quran

${ }^{11}$ Ibid., hlm. 118 
Penilaian kebiasan membaca Al-Quran

\begin{tabular}{|c|c|c|c|c|c|c|}
\hline Nam & Siswa & & & & & \\
\hline Oran & Tua/ wali & & & & & \\
\hline Kelas & Semester & & & & & \\
\hline No. & $\begin{array}{l}\text { Hari/ } \\
\text { Tanggal }\end{array}$ & Jam & Surat & Juz & Ayat & $\begin{array}{c}\text { Tanda } \\
\text { Tangan } \\
\text { Orang Tua }\end{array}$ \\
\hline 1 & & & & & & \\
\hline 2 & & & & & & \\
\hline 3 & & & & & & \\
\hline 4 & & & & & & \\
\hline
\end{tabular}

Bantul, ..........Mei 2019

Guru PAI

Orang Tua/ Wali

b. Skala Sikap

Ada beberapa skala yang bisa digunakan dalam mengukur sikap seseorang di antaranya adalah skala sikap Likert dan Skala Differensial Semantik.

Skala likert adalah sebuah Teknik pengukuran yang sederhana yang paling sering dijumpai dalam pengukuran afektif, khususnya untuk pengukuran dalam sikap. Skala likert mempunyai prinsip dimana skala likert ini menyajikan pernyataan yang harus ditanggapi diantara 5 alternatif: sangat setuju, setuju, ragu-ragu, tidak setuju, dan sangat tidak setuju. ${ }^{12}$

Contoh :

Nama :

Kelas :

12 Supardi, Penilaian Autentik Pembelajaran Kognitif, Afektif, dan Psikomotorik, (Jakarta: Rajagrafindo persada, 2015), hlm. 127 
Petunjuk : bacalah pernyataan dibawah ini dengan baik, kemdian berilah tanda silang (X) pada kolom yang sesuai dengan perasaan anda, dan pengalaman anda!

\begin{tabular}{|c|l|c|c|c|c|c|}
\hline No & Pernyataan & SS & S & N & TS & STS \\
\hline 1. & $\begin{array}{l}\text { Berbuat baik disnjurkan oleh } \\
\text { islam }\end{array}$ & & & & & \\
\hline 2. & $\begin{array}{l}\text { Berbuat baik akan berdampak } \\
\text { baik bagi diri sendiri }\end{array}$ & & & & & \\
\hline 3. & Berbuat baik disenangi orang lain & & & & & \\
\hline 4. & $\begin{array}{l}\text { Perbuatan baik akan dibalaskan } \\
\text { di dunia dan di akhirat }\end{array}$ & & & & & \\
\hline 5. & $\begin{array}{l}\text { Perbuatan baik harus dilakukan } \\
\text { setiap orang }\end{array}$ & & & & & \\
\hline
\end{tabular}

Skala Sematik Differensial Adalah Teknik pengukuran yang menampilkan pernyataan dengan objek baik berupa konsep atau perilaku. Skala beda semantik ini menggunakan garis kontinum dengan jawaban yang sangat postif terletak di seblah kiri garis, dan jawaban yang sangat negatif terletak di sebelah kanan garis. ${ }^{13}$

Contoh : Sikap pandangan peserta didik terhdap nilai kerja sama menggunakan nilai kerja sama

Nama :

Kelas :

Petunjuk : Bacalah pernyataan dibawah ini dengan baik, dan berilah (x) angka $1,2,3,4,5,6$, atau 7 yang sesuai dengan perasaan dan pengalaman anda

13 Ibid., hlm. 130 


\begin{tabular}{|l|l|l|l|l|l|l|l|l|l|}
\hline \multirow{2}{*}{ No } & \multirow{2}{*}{ Pernyataan } & \multicolumn{6}{|c|}{ Skala Beda Semantik } & \multirow{2}{*}{ Pernyataan } \\
\cline { 3 - 8 } & & 7 & 6 & 5 & 4 & 3 & 2 & 1 & \\
\hline 1 & menyenangkan & & & & & & & & Membosankan \\
\hline 2 & Mudah & & & & & & & & Sulit \\
\hline 3 & Bermanfaar & & & & & & & & Sia-sia \\
\hline 4 & Menanntang & & & & & & & & Menjenuhkan \\
\hline 5 & Banyak & & & & & & & & Sedikit \\
\hline
\end{tabular}

\section{c. Skala Minat}

Aspek minat peserta didik yang perlu diukur oleh guru adalah minat peserta didik terhadap mata pelajaran tertentu. Salah satu untuk megukur minat ini menggunakan skala minat. ${ }^{14}$

Contoh: skala minat terhadap pelajaran PAI di sekolah sebagai berikut: Minat Siswa terhadap mata pelajaran Fikih.

Nama :

Kelas :

Mata Pelajaran :

\begin{tabular}{|l|l|l|l|l|l|}
\hline \multirow{2}{*}{ No } & \multicolumn{1}{|c|}{ Pernyataan } & \multicolumn{4}{|c|}{ Skala } \\
\cline { 5 - 6 } & & SS & S & TS & STS \\
\hline 1 & Saya Senang mengikuti pelajaran ini & & & & \\
\hline 2 & Saya rugi menguti pelajaran ini & & & & \\
\hline 3 & Saya merasa pelajaran ini bermanfaat & & & & \\
\hline 4 & $\begin{array}{l}\text { Saya berusaha menyampaikan tugas } \\
\text { tepat waktu }\end{array}$ & & & \\
\hline 5 & $\begin{array}{l}\text { Saya bertanya kepada guru bila ada yng } \\
\text { tidak jelas }\end{array}$ & & & & \\
\hline
\end{tabular}

${ }^{14}$ Sukiman, Sistem Penilaian Pembelajaran, hlm. 127-128 


\section{Penilain Teman Sejawat}

Teknik penilaian dengan cara meminta peserta didik untuk saling menilai terkait kelebihan dan kekurangan yang dimiliki dan pencapaian kompetensi yang telah dirumuskan ${ }^{15}$.

Instrumen yang dapat digunakan untuk penilaian antarpeserta didik adalah daftar cek. Daftar cek ini dapat digunakan untuk mengukur penilaian teman sejawat karena daftar cek merupakan daftar tingkah laku untuk pengamatan dalam mengecek apakah tingkah laku yang tercantum muncul dalam daftar (ada atau ya) atau tidak muncul (tidak ada atau tidak). ${ }^{16}$

\section{Lembar penilaian antar peserta didik Sikap disipilin}

Petunjuk: Berilah tanda cek (V) pada kolom skor sesuai sikap kedisipilinan yang ditampilkan oleh peserta didik, dengan kriteria sebagi berikut:

$\mathrm{Ya}=$ Apabila peserta didik menunjukan perbuatan sesuai aspek pengamatan

Tidak $=$ Apabila peserta didik tidak menunjukan perbuatan sesuai aspek pengamatan.

Nama Penilai :

Nama Peserta didik yang dinilai:

Kelas

Mata pelajaran

\begin{tabular}{|l|l|l|l|}
\hline \multirow{2}{*}{ No } & \multicolumn{1}{|c|}{ Sikap yang diamati } & \multicolumn{2}{c|}{ Melakukan } \\
\cline { 3 - 4 } & & Ya & Tidak \\
\hline 1 & Masuk kelas tepat waktu & & \\
\hline 2 & Mengumpulkan tuga tepat waktu & & \\
\hline 3 & Tertib dalam mengikuti pelajaran & & \\
\hline 4 & Memakai seragam dengan tertib & & \\
\hline 5 & Memabawa buku teks mata pelajaran & & \\
\hline
\end{tabular}

15 Ibid., hlm. 129-130

${ }^{16}$ Supratiknya, Penilaian Hasil Belajar dengan Teknik Nontes (Yogyakarta: Unversitas Sanata Dharma, 2012), hlm. 43 
4. Wawancara

Adalah salah satu Teknik pengumpulan dan pencatatan data, informasi, dan atau pendapat yang dilakukan melalui percakapan dan tanya-jawab, baik langsung maupun tidak langsung dengan sumber data. ${ }^{17}$

Sebagai Teknik penilaian, wawancara dapat digunakan untuk menilai proses maupun hasil pembelajaran. Menilai proses pembelajaran misalnya menilai efektifitas penggunaan metode, mendia pembelajaran, maupun sistem penialain yang diterapkan guru. Menilai hasil pembelajaran misalnya menilai sikap, minat, sera kebiasaan peserta didik setelah proses pembelajaran seperti kebiasaan melaksanakan shalat, kebiasaan bersikap jujur, adil, ataupun menjauhi perilaku yang tidak baik.

Berikut adalah contoh Teknik dan instrument wawancara untuk menilai tingkat keyakinan peserta didik terhadap Allah swt sebagai Sang Pencipta.

Nama :

Kelas :

\begin{tabular}{|l|l|l|l|}
\hline No & \multicolumn{1}{|c|}{ Pertanyaan } & \multicolumn{1}{|c|}{$\begin{array}{c}\text { Jawaban } \\
\text { peserta didik }\end{array}$} & $\begin{array}{c}\text { Komentar dan } \\
\text { Kesimpulan hasil } \\
\text { wawancara }\end{array}$ \\
\hline 1. & $\begin{array}{l}\text { Allah swt telah } \\
\text { menciptakan manusia } \\
\text { dengan bentuk yang sangat } \\
\text { sempurna }\end{array}$ & $\begin{array}{l}\text { Bagaimanakah perasaan } \\
\text { anda ketika mendngarkan } \\
\text { ayat-ayat Al-Quran yang } \\
\text { sedang dibaca? }\end{array}$ & \\
\hline 2. & & \\
\hline
\end{tabular}

${ }^{17}$ Sukiman, Sistem Penilaian Pembelajaran, hlm. 134. 
5. Jurnal

Jurnal merupakan catatan pendidik di dalam dan di luar kelas yang berisi informasi hasil pengamatan tentang kekuatan dan kelemahan peserta didik yang berkaitan dengan kinerja atau sikap peserta didik yang dipaparkan secara deskriptif. ${ }^{18}$

Terkait dengan pencatatan jurnal, maka guru perlu mengenal dan memperhatikan perilaku peserta didik baik di dalam kelas maupun di luar kelas. Aspek-aspek pengamatan ditentukan terlebih dahulu oleh guru sesuai dengan karakteristik mata pelajaran yang diajar. Aspek-aspek pengamatan yang sudah ditentukan tersebut kemudian dikomunikasikan terlebih dahulu dengan peserta didik di awal semester.

Nilai = Sangat Baik (SB), Baik (B), Cukup (C), dan Kurang (K) ditentukan dengan cara menghitung rata-rata skor dan membandingkan dengan kriteria penilaian. Contoh istrumen jurnal:

Nama Peserta Didik :

Aspek yang diamati : Sikap Sosial

\begin{tabular}{|l|l|l|l|}
\hline No & Hari/ Tanggal & Kejadian & Keterangan \\
\hline 1 & & & \\
\hline 2 & & & \\
\hline
\end{tabular}

\section{Pelaksanaan penilaian afektif}

Awal pembelajaran guru menyampaikan indikator dan tujuannya pembelajaran. Kompetensi sikap terbagi menjadi dua yaitu sikap spiritual dan sosial. Guru menyampaikan kompetensi sikap yang akan dinilai, untuk penilaian sikap spiritual melalui observasi guru melakukan saat proses pembelajaran berlangsung contohnya

\footnotetext{
${ }_{18}$ Bambang Subali, Prinsip Asesmen dan Evaluasi Pembelajaran, (Yogyakarta: UNY Press, 2016),
} hlm. 61 
berdoa sebelum dan setelah proses pembelajaran, untuk penilaian sikap sosial melalui observasi guru melakukan saat proses pembelajaran, contohnya dalam hal kedisiplinan, kepercayadirian dan kesantunan dikelas.

Untuk penilaian sikap diri sendiri, guru membagikan formulir ke siswa dan diisi oleh siswa dirumah dan penilaian ini hanya dilakukan dalam jangka satu minggu. Selanjutnya penilaian teman sejawat, penilaian ini juga hanya dilakukan satuu minggi satu kali tetapi dihari yang beda beda agar siswa selalu siap dalam proses pembelajaran, untuk penilaian teman sejawat ini siswa diberikan formulir yang berisi tentang bagaimana keadaan temanmu? Untuk pemilihan penilaian guru yang menentukan siapa yang dinilai dan yang menilai agar tidak adanya kesenjangan dalam pertemanan dan dirahasiakan penilaiannya. ${ }^{19}$

\section{Dampak implementasi penilaian sikap terhadap siswa}

Dengan pengambilan nilai sikap yang secara ajeg mampu mempengaruhi sikap siswa, siswa selalu berusaha berubah menjadi lebih baik untuk dinilai oleh guru, diri sendiri atau temannya. Dengan menerapkan penilaian ini maka sikap siswa akan menjadi kebiasaan dalam kesehariannya tanpa harus disuruh maupun tanpa harus embel-embel mendapatkan nilai yang bagus tetapi sudah mendarah daging pada dirinya sendiri. Tetapi hasil dari penilaian sikap ini tidak langsung terasa atau terlihat, biasanya akan dilihat pada jenjang kelas yang lebih tinggi, apakah siswa itu dapat berubah atau tidak dan penilaian sikap diterapkan secara terus menerus dan berlanjut selama 6 tahun atau dalam jenjang siswa tersebut bersekolah di SDN Gunungsaren. Hasil maksimal dari penilaian sikap akan terlihat pada kelas 6 atau di akhir siswa itu bersekolah. $^{20}$

Penilaian sikap ini mampu membentuk sikap siswa, perilaku yang menjadi kebiasaan sehari-hari. Deskripsi penilaian sikap yang diterapkan dalam sekolah ini adalah sebagai berikut:

${ }^{19}$ Wawancara dengan ibu Kartika Juliana, S.Pd, tetang pelaksanaan penilaian sikap, pada hari Kamis tanggal 9 Mei 2019.

20 Wawancara dengan ibu Kartika Juliana, S.Pd, tetang dampak pelaksanaan penilaian sikap, pada hari Kamis tanggal 9 Mei 2019. 


\begin{tabular}{|l|l|l|}
\hline No. & Nilai & Deskripsi \\
\hline 1. & Spiritual & $\begin{array}{l}\text { Taat beribadah, bersyukur, berdo'a, dan } \\
\text { toleransi }\end{array}$ \\
\hline 2. & Sosial & Jujur, disiplin, percaya diri dan santun. \\
\hline
\end{tabular}

\section{KESIMPULAN}

Kurikulum 2013 telah dilaksanakan oleh SDN Gunungsaren Bantul sehingga tujuan dari keberhasilan pendidikannya bukan hanya membuat siswa cerdas tetapi juga membuat siswa cerdas, berketrampilan dan mempunyai akhlak mulia.

Dalam penelitian ini yang meneliti tentang penilaian sikap di SDN Gunungsaren, guru telah melakukan penilaian sikap, dan penilaian sikap dilakukan dengan teknik observasi yaitu guru melakukan penilaian observasi kepada seluruh siswa dengan mencata dilembar observasi, penilaian diri yaitu siswa mencatat penilaian dirinya di lembar formulir yang sudah diberikan oleh guru dan penilaian teman sejawat yaitu siswa menilai temannya sendiri dan jurnal yaitu keseharian diluar sekolah dan ditandatangani oleh orang tua.

Hasil penelitian yang dilakukan oleh peneliti dampak dari penilaian sikap ini, siswa berusaha untuk merubah dirinya menjadi lebih baik, yang awalnya hanya ingin mendapatkan nilai yang baik tetapi dilakukan secara terus menerus sehingga mendarah danging dan menjadi kebiasaan siswa.

\section{DAFTAR PUSTAKA}

Arikunto, Suharsimi. 2007. Prosedur Penelitia: Suatu Pendekatan Praktik. Jakarta: Bumi Aksara.

Azwar, Syifuddin. 1998. Metode Penelitian. Yogyakarta: Pustaka Pelajar.

Hasan, Risqyanto. Inovasi Strategi Pembelajaran Inkuiri dalam Pembelajaran. Dalam Jurnal Palapa: Jurnal Studi Keislaman dan Ilmu Pendidikan. Volume 7. Nomor 1. Mei 2019.

Mursal. Pendidikan Afektif Dalam Perspektif Hasan Langgulung. dalam jurnal Al-Fikra: Jurnal Ilmiah Keislaman. Volume 12. Nomor 1. Januari - Juni 2013.

Peraturan Menteri Agama No. 165 Tahun 2014 
Setiadi, Hari. Pelaksanaan Penilaian Pada Kurikulum 2013. Dalam Jurnal Penelitian dan Evaluasi Pendidikan. Volume 20. Nomor 2. Desember 2016.

Subali, Bambang. 2016. Prinsip Asesmen dan Evaluasi Pembelajaran. Yogyakarta: UNY Press.

Sukiman. 2017. Sistem Penilaian Pembelajaran. Yogyakarta: Media Akademi.

Supardi. 2015. Penilaian Autentik Pembelajaran Kognitif, Afektif, dan Psikomotorik. Jakarta: Rajagrafindo persada.

Supratiknya. 2012. Penilaian Hasil Belajar dengan Teknik Nontes. Yogyakarta: Unversitas Sanata Dharma.

Tiara, Shintia Kandita. Analisis Teknik Penilaian sikap Sosial Siswa dalam Penerapan Kurikulum 2013 Di SDN 1 Watulimo. Dalam jurnal EduHumaniora: Jurnal Pendidikan Dasar. Volume 11. Nomor 1. Januari 2019.

Wawancara dengan ibu Kartika Juliana, S.Pd, tentang perencanaan penilaian sikap, pada hari Kamis tanggal 9 Mei 2019.

Wawancara dengan ibu Kartika Juliana, S.Pd, tetang pelaksanaan penilaian sikap, pada hari Kamis tanggal 9 Mei 2019.

Wawancara dengan ibu Kartika Juliana, S.Pd, tetang dampak pelaksanaan penilaian sikap, pada hari Kamis tanggal 9 Mei 2019. 